\title{
BMSAP
}

Bulletins et mémoires de la Société d'Anthropologie de Paris

BMSAP

$33(1) \mid 2021$

Les 1000 premiers jours de vie dans les populations du présent et du passé

\section{À 162 ans, les Bulletins et Mémoires de la Société d'Anthropologie s'engagent pour une science ouverte et passent en accès libre et gratuit}

Building on 162 years of scientific publication, the Bulletins et Mémoires de la Société d'Anthropologie introduces unlimited free access to enter the world of open science

Aurélien Mounier, Sacha Kacki, Antoine Balzeau, Benoît Bertrand, Céline Bon, Cécile Buquet-Marcon, Guillaume Daver, Karina Gerdau, Morgane Gibert, Gwenaëlle Goude, Franck Guy, Anne Le Maître, François Marchal, Olivia Munoz et Camille Noûs

\section{(2) OpenEdition}

Journals

Édition électronique

URL : https://journals.openedition.org/bmsap/7438

DOI : $10.4000 /$ bmsap.7438

ISSN : $1777-5469$

Éditeur

Société d'Anthropologie de Paris

Référence électronique

Aurélien Mounier, Sacha Kacki, Antoine Balzeau, Benoît Bertrand, Céline Bon, Cécile Buquet-Marcon, Guillaume Daver, Karina Gerdau, Morgane Gibert, Gwenaëlle Goude, Franck Guy, Anne Le Maître, François Marchal, Olivia Munoz et Camille Noûs, «À 162 ans, les Bulletins et Mémoires de la Société d'Anthropologie s'engagent pour une science ouverte et passent en accès libre et gratuit », Bulletins et mémoires de la Société d'Anthropologie de Paris [En ligne], 33 (1) | 2021, mis en ligne le 27 avril 2021, consulté le 14 novembre 2022. URL : http://journals.openedition.org/bmsap/7438 ; DOI : https:// doi.org/10.4000/bmsap.7438

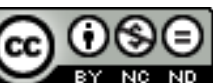

Creative Commons - Attribution - Pas d'Utilisation Commerciale - Pas de Modification 4.0 International - CC BY-NC-ND 4.0

https://creativecommons.org/licenses/by-nc-nd/4.0/ 


\title{
À 162 ans, les Bulletins et Mémoires de la Société d'Anthropologie s'engagent pour une science ouverte et passent en accès libre et gratuit
}

\author{
Building on 162 years of scientific publication, the Bulletins et Mémoires de la Société \\ d'Anthropologie introduces unlimited free access to enter the world of open science
}

\author{
Aurélien Mounier (DD 1,2*, Sacha Kacki (D) 3,4, Antoine Balzeau (D) 1,5, Benoît Bertrand (D) 1,6 , Céline Bon7, \\ Cécile Buquet-Marcon ${ }^{8}$, Guillaume Daver ${ }^{9}$, Karina Gerdau ${ }^{10}$, Morgane Gibert ${ }^{11}$, Gwenaëlle Goude (D) ${ }^{12}$, \\ Franck Guy (D) ${ }^{9}$, Anne Le Maître (D) ${ }^{9,13}$, François Marchal ${ }^{14}$, Olivia Munoz (D) ${ }^{15}$, Camille Noûs ${ }^{16}$
}

1 Histoire Naturelle de l'Homme Préhistorique (HNHP, UMR 7194), MNHN/CNRS/UPVD, Musée de l'Homme, Paris, France

2 Leverhulme Centre for Human Evolutionary Studies, Department of Archaeology, University of Cambridge, United Kingdom

3 UMR 5199 PACEA, CNRS - Université de Bordeaux, Pessac, France

4 Department of Archaeology, Durham University, Durham, United Kingdom

5 Department of African Zoology, Royal Museum for Central Africa, Tervuren, Belgium

6 Univ Lille, CHU Lille, EA 7367 - UTML - Unité de Taphonomie Médico-Légale, Lille, France

7 UMR 7206 Eco-anthropologie, Musée de l'Homme, Paris, France

8 INRAP / UMR 7206 Eco-anthropologie, Pantin, France

9 Université de Poitiers - Faculté des Sciences, CNRS UMR 7262 PALEVOPRIM, Poitiers, France

10 UMR 7044 Archimède, Université de Strasbourg, Strasbourg, France

11 Laboratoire AMIS - UMR 5288, Faculté de Médecine Purpan, Toulouse, France

12 Aix-Marseille Université, CNRS, Ministère de la Culture, UMR 7269 LAMPEA, France

13 Department of Evolutionary Biology - Unit for Theoretical Biology, University of Vienna, Vienna, Austria

14 UMR 7268 ADES, Aix Marseille Univ, CNRS, EFS, Marseille, France

15 UMR 8215 Trajectoires, Paris, France

16 Laboratoire Cogitamus, Musée de l'Homme, Paris, France

*aurelien.mounier@mnhn.fr

\section{Version française}

La Société d'Anthropologie de Paris édite depuis 1859 les Bulletins et Mémoires de la Société d'Anthropologie de Paris (BMSAP). Nos bulletins sont ainsi la plus ancienne revue scientifique au monde dans le domaine de l'anthropologie biologique. Cette longévité est le résultat du soutien indéfectible de notre communauté à sa revue, que ce soit par les contributions scientifiques qui l'ont alimentée, par la fidélité de ses abonnées et abonnés jusqu'en 2020 et par tout le travail effectué par les équipes qui se sont succédé à la rédaction. Que tous les acteurs et actrices de cette réussite en soient vivement remerciés.

$\mathrm{Si}$, depuis de nombreuses années, les contenus scientifiques publiés dans les BMSAP sont accessibles dès leur publication en ligne par abonnement (institutionnel ou personnel) et, dans une majorité des cas, en accès libre après deux ans, le mode de fabrication de nos Bulletins a varié à de nombreuses reprises. De 1859 à 2009, les BMSAP étaient intégralement produits par les membres du comité de rédaction et, entre 2000 et 2009, diffusés sur la plateforme Open Edition Journals. À partir de 2010, au vu de la charge de travail que représentait la fabrication de notre revue, la Société d'Anthropologie de Paris a confié à des maisons d'éditions professionnelles sa diffusion : Springer de 2010 à 2015 et Lavoisier de 2016 à 2020. Le passage des BMSAP chez ces éditeurs professionnels a permis aux membres du comité de rédaction de se concentrer sur la partie la plus importante du travail d'édition : la partie scientifique. Ce mode de diffusion a aussi permis, un temps, d'augmenter la diffusion de nos Bulletins, grâce aux bouquets d'abonnements proposés par ces éditeurs. Le prix de cette liberté scientifique est néanmoins important et entre 2010 et 2020 , le mode de diffusion des bulletins scientifiques de la Société d'Anthropologie de Paris se trouvait en contradiction profonde avec les valeurs de science ouverte portées par la SAP et, par extension, par les BMSAP.

C'est dans ce contexte qu'en 2018 le conseil d'administration de la SAP et le comité de rédaction des BMSAP ont lancé une réflexion sur l'avenir de la diffusion de notre revue qui devait répondre à trois objectifs principaux : assurer la meilleure diffusion possible de nos Bulletins, garantir la pérennité de la plus ancienne revue scientifique en anthropologie biologique et, peut-être le plus important, assurer l'accessibilité la plus large possible des contenus scientifiques.

Par conséquent, le contrat de diffusion avec Lavoisier, qui arrivait à son terme le 31 décembre 2020, n'a pas été renouvelé et nous avons décidé de confier de nouveau la 
diffusion des BMSAP à OpenEdition Journals. Ce retour chez OpenEdition Journals s'accompagne d'une nouvelle politique de diffusion puisque les BMSAP sont désormais accessibles gratuitement en intégralité dès la publication des manuscrits sans pour autant engendrer de frais de publication pour les auteur.es (open access diamant). Les abonnements aux BMSAP disparaissent donc en 2021.

Pour assurer cette rupture de politique éditoriale, et audelà du soutien constant de l'Institut national des Sciences Humaines et Sociales (InSHS) du CNRS, les BMSAP ont obtenu un financement pour les trois prochaines années du Fond National pour la Science Ouverte qui nous permet d'envisager sereinement notre transition. Ces fonds seront utilisés pour externaliser vers un prestataire la mise en page et la mise en ligne des manuscrits, mais aussi la réalisation des deux numéros annuels des BMSAP. Ils seront disponibles gratuitement en avril et octobre de chaque année aux formats pdf et epub (pour liseuses électroniques). L'impression des Bulletins ne pourra malheureusement pas être poursuivie dans ce nouveau modèle économique. Cette décision s'inscrit également dans le contexte général de l'évolution du paysage de l'édition scientifique et traduit notre volonté de permettre un accès libre et gratuit à l'information scientifique.

Cet éditorial inaugure ainsi l'entrée des BMSAP, après 162 ans d'existence, dans l'univers de la diffusion ouverte et libre des connaissances. Vous le lisez peut-être dans sa version en ligne, ou dans sa version pdf (fac-similé), mais vous pouvez le retrouver intégré dans notre numéro 33(1) d'avril 2021 au format pdf ou epub.

L'ensemble de nos nouveaux contenus scientifiques est désormais disponible sur notre site OpenEdition Journals qui a remplacé et amélioré le site en service entre 2000 et 2009. Ce site a la particularité de réunir la quasi intégralité des manuscrits publiés dans les BMSAP depuis leur création en 1859. Sous l'onglet "numéros sur Persée" vous pouvez retrouver les numéros publiés entre 1864 et 1999 et sous l'onglet "numéros 2000-2009" ceux publiés entre 2000 et

\section{English version}

The Société d'Anthropologie de Paris has been publishing the Bulletins et Mémoires de la Société d'Anthropologie de Paris (BMSAP) since 1859, making our publication the world's oldest scientific journal in the field of biological anthropology. This longevity is the result of our community's unwavering support for its journal, through the scientific contributions received, the loyalty of our subscribers up to 2020 and the constant efforts of the journal's successive editorial teams. Our warmest thanks go to all who have contributed to this success.

While the scientific content published in the BMSAP has been available online to institutional or individual subscribers for many years and, in most cases, by open access after two years, our journal's production system has changed several times. From 1859 to 2009, all BMSAP issues were produced entirely by members of the editorial committee
2009. Les numéros publiés chez Springer entre 2010 et 2015 restent accessibles via les bouquets d'abonnement de Springer. Ceux publiés chez Lavoisier entre 2016 et 2020 sont en ligne sur le site de Lavoisier et deviennent accessibles gratuitement deux ans après leur publication. Vous pourrez dès la fin du mois d'avril 2021 profiter gratuitement des contenus publiés jusqu'au numéro 31(1-2) d'avril 2019, qui explorait les innovations et les nouvelles questions posées par la variabilité morphologique en paléoanthropologie. Nous travaillons actuellement avec OpenEdition Journals pour que dans les mois et années qui viennent, ces contenus soient republiés sur notre nouveau site, permettant ainsi de réunir sur une unique plateforme l'ensemble des numéros des BMSAP publiés.

C'est ainsi une nouvelle ère qui s'ouvre pour notre revue, tournée vers le partage sans limite de l'information scientifique dans ce qui est déjà une tendance forte financée par la plupart des pays du monde et sera de ce fait, nous l'espérons ardemment, l'avenir de l'édition scientifique internationale. La qualité du suivi scientifique et éditorial des contributions reçues continuera à respecter les standards les plus élevés de la production scientifique tout en restant totalement gratuit pour les chercheuses et chercheurs qui soumettront leurs travaux. À nos yeux, les modes de diffusion des connaissances scientifiques doivent être les plus ouverts possibles et accessibles au plus grand nombre, acteurs de la recherche et grand public. Les résultats de la science, déjà financés par des fonds publics, ne doivent en aucun cas servir la spéculation et le financement d'acteurs privés dont l'apport est négligeable si tous les acteurs scientifiques et politiques jouent ensemble le jeu de la science ouverte.

Tout est donc en place pour que notre revue vive encore au moins 162 ans. Elle n'a plus besoin que d'une chose pour ce faire : recevoir en nombre vos contributions scientifiques. Alors continuons à faire vivre tous ensemble notre chère revue.

À bientôt

and, from 2000 to 2009, distributed through the OpenEdition Journals platform. In 2010, given the workload involved in producing the journal, the Société d'Anthropologie de Paris (SAP) entrusted its distribution to professional publishing companies: Springer from 2010 to 2015, then Lavoisier from 2016 to 2020 . With the transfer of BMSAP distribution to these companies, the editorial team was able to concentrate on the most important part of its editing work: the scientific aspect. These distribution channels also, for a time, increased our journal's circulation, thanks to the subscription packages offered by the distributors. However, this scientific freedom came at a price, and from 2010 to 2020, the distribution method for the scientific bulletins of the Société d'Anthropologie de Paris was in profound contradiction with the open science values of the SAP and, by extension, of the BMSAP. 
This was the context in which the SAP Board of Directors and the BMSAP editorial committee launched discussions on the future of our journal's distribution, which needed to satisfy three main aims: achieving the best possible circulation of our Bulletins while guaranteeing the permanence of the world's oldest scientific journal in the field of biological anthropology and, perhaps most importantly, ensuring the widest possible access to their scientific content.

Consequently, the distribution contract with Lavoisier, which was to expire on 31 December 2020, was not renewed and we decided to hand BMSAP distribution back to Open Edition Journals. At the same time, we introduced a new distribution policy so that the entire BMSAP content is now available free of charge as soon as the manuscripts are published, with no publication costs incurred by the authors ("diamond open access"). Subscriptions to the BMSAP will therefore be dropped in 2021.

To secure this policy change, over and above the continuing support provided by the National Institute of Human and Social Sciences (InSHS) of the CNRS, the BMSAP has obtained funding for the next three years from the National Open Science Fund, allowing us to plan ahead for our transition with confidence. These funds will be used to outsource the layout and online publishing of the manuscripts, but also the production of the two annual issues of the BMSAP. These issues will be available free of charge in April and October of each year in pdf and epub formats (for e-readers). Unfortunately, this new business model will not allow us to maintain the print version of the BMSAP. However, this decision is in line with the overall trend in the landscape of scientific publishing as well as with our aim of providing free and open access to scientific information.

This editorial thus inaugurates the BMSAP's entry, after 162 years of existence, into the world of free and open access to knowledge. You may be reading it on line or in the pdf (facsimile) version, but it will also be published in pdf or epub in our April 2021 issue, no. 33(1).

All of our new scientific content is now available on our new OpenEdition Journals site, which replaces and improves on the previous 2000-2009 version. In particular, the site contains virtually all of the manuscripts published in the BMSAP journal since its creation in 1859. The "numéros sur Persée" tab will take you to the issues published from 1864 to 1999 and the "numéros 2000-2009" tab to issues published from 2000 to 2009 . The issues published by Springer from 2010 to 2015 can still be accessed via the Springer subscription packages, while those published by Lavoisier from 2016 to 2020 are available online on the Lavoisier site, becoming free of charge two years after their publication date. From the end of April 2021, access will be free of charge for content published up to issue 31(1-2) (April 2019), which explores the innovations and new questions raised by morphological variability in palaeoanthropology. We are currently working with OpenEdition Journals to republish this content on our new site in the months and years to come, so that every published BMSAP issue can be accessed from a single platform.

These developments open up a new era for our journal, geared to unrestricted sharing of scientific information in an age where it is already expanding rapidly with funding from most of the world's countries and which, we fervently hope, will be the future of international scientific publishing. The quality of scientific and editorial reviews of contributions received will continue to maintain the highest standards in scientific production, without cost to the researchers submitting their work. In our view, channels of distribution for scientific knowledge must be as open as possible and accessible to as many people as possible, both those involved in research and the general public. If all scientific and political players abide by the rules of open science together, the results of scientific research which is already funded by taxpayers should not be used for speculation and financing for privatesector players whose contribution to Science is negligible.

Everything is now set up for our journal to thrive for another 162 years, at least. It only needs one more thing: your scientific contributions, and as many as possible! So let us keep our cherished journal alive together.

With best wishes to you all 